\title{
Tipicidade e atipicidade nos atos administrativos.
}

\author{
Fernando Henrique Mendes de Almeida

Livre-Docente de Direito Administrativo da
Faculdade de Direito da Universidade de
São Paulo.

I.

Prolegómenos.

1. A compreensão do presente escôrço exigirá do seu Ieitor inteira atenção para as idéias que, a seguir, vamos colocar em foco. Da atividade que o Estado realiza para cumprir seus fins essencial e acidental, parte, pressupondo contenda, exige distribuição de justiça e, assim, atos de jurisdição. Mas, outra parte, bem mais extensa do que se supõe à primeira vista, porque não a exige e até vem a ser meio de promover o bem-estar dos administrados, é atividade que não pressupõe contenda e, portanto, ou diz respeito à fase de estruturação do Estado (regida pelo Direito Constitucional) ou se endereça diretamente ao Direito Administrativo como: a) atividade por que o Estado tutela o Direito, ainda que sem distribuir justiça (atividade Jurídica não contenciosa) b) atividade para realização de bem-estar de todos os administradores. É o que, no nosso entender, pode ser chamado: atos administrativos em gênero, procedam êles de qualquer dos três poderes em que se resolve a divisão de trabalho da Soberania. 
2. Dos atos administrativos em gênero podem-se distinguir, em face das idéias que acabamos de reproduzir, aquêles que se reconhecem fàcilmente como fatôres da tutela do direito, sem envolver demanda, e como fatôres do bem-estar dos administrados, aquêles que o Executivo realiza habitualmente e aquêles que, realizados por outros poderes do Estado (Legislativo e Judiciário) são formal e materialmente tarefas em que nem de longe deve ser lembrada a idéia de jurisdição. São os atos administrativos típicos, como, por exemplo, uma nomeação de funcionários por um dos três poderes. Contudo, há, ao lado dêsses atos ora recognocíveis pela procedência (Executivo) ora recognociveis pela substância (as do Legislativo e os do Judiciário, como no caso do exemplo acima apontado) outros que emergem de tarefas judiciárias e de órgãos auxiliares. ou, ainda, de tarefas do Legislativo e, embora pela forma possam, por mera tradição doutrinária, parecer estranhos ao Direito Administrativo, não o são. Não o são e ao contrário do que se pensa, constituem a categoria dos atos administrativos atípicos, arrebatados do território da nossa disciplina e aclimados no Direito Judiciário, principalmente, em obediência apenas a razões de método. Referimo-nos aos: a) atos da chamada "Jurisdição graciosa", quanto ao Poder Judiciário; b) atos de expediente das secretarias de quaisquer ramos do Legislativo; c) atos de órgãos da fé pública.

3. Os atos da chamada "jurisdição graciosa" são aquêles em que, em acuda de administrado e porque as leis o impõem, o juiz aparece e, no entanto, não pondo têrmo a demanda alguma porque esta não existe, tutela direito, sem distribuir justiça. São, portanto, atos que não envolvem jurisdição e, assim, se resolvem em atividade jurídica não contenciosa judiciária. Os atos de expediente das mesas legislativas, pela mesma razão, são atividade jurídica não contenciosa e, assim, aquêles que, para o bem da segurança dos negócios particulares, os órgãos do tabelioado e das escrivanias realizam para os administrados porque a lei o 
ämpõe. Dêstes últimos e dos primeiros, dissemos, já, que constituem:

atos administrativos atinentes à Administração Pública do Direito Privado, praticados:

a) pelas autoridades judiciárias;

b) pelos órgãos auxiliares da Justiça (órgãos da fé pública).

Êles, porém, se podem considerar, antes de mais nada, atos administrativos atípicos, porque administrativos materialmente (visto que não contenciosos) na forma não oferecem meios de fácil identificação em virtude de uma destas circunstâncias :

I) provirem de órgãos judiciários e auxiliares dêstes;

II) terem forma de atos de jurisdição ou de meios de satisfação das provas, sem serem jamais jurisdição.

4. A atipicidade realmente favoreceu no passado, como no presente ainda favorece, o método de ensinar Direito Judiciário. Mas, se assim foi e assim é, colocou os mestres desta disciplina na necessidade de dar à palavra jurisdição elasticidade tal, que não encontra eco na realidade das cousas e, sobretudo, perde valia, quando é observado que o juiz (autoridade específica para a função de dizer do direito para pôr têrmo a demanda), embora atenda, pela jurisdição à causa final do Poder Judiciário, é, na prática, bem mais realizador de Administração Pública dó que se supõe, visto como maior é o número de suas tarefas em que não existe o pressuposto da contenda do que o daqueles em que ela existe.

\section{II.}

A atipicidade e suas espécies.

5. A atipicidade no chamado "ato de jurisdição graciosa" pode provir de resistência doutrinária. Não levare- 
mos em conta esta atitude mental, porquanto: embora entre processualistas haja divisão de correntes acêrca da pertinência dêsse território do Direito Administrativo no Direito Judiciário, as formas do "gracioso" ainda se encontram nos. códigos de processo civil e aos mestres da última disciplina referida compete ensiná-las. Mas, a atipicidade que impressiona, no caso, realmente, pode provir:

a) da circunstância de o Juiz, aos olhos do vulgo, não ser administrador; ou,

b) da circunstância de alguns órgãos da fé pública serem decorrência de espécies do gênero de conferimento. de exercício privado do serviço público, como é o caso dos taßeliães, cujos serventuários não têm a qualidade de funcionários públicos.

Relativamente à primeira questão, seria preciso que a idẻia de Administração Pública em sentido objetivo e material fôsse privativo do Executivo, para que o Juiz-Administrador fôsse uma aberração. Ora, o Juiz-Administrador é regra; o Juiz-Distribuidor da Justiça através da Jurisdição é que é exceção.

Quanto à segunda questão, que é de discutibilidade imensa, não se concebe que a fé pública, como serviço público, seja exercida a título privado, para o efeito de o tabelião e seu oficial-maior serem funcionários e não o serem os empregados do tabelionato, porque o ato administrativo emanado de agente incompetente é nulo e, com maior razão, se emanado de quem não é funcionário ao menos no sentido formal.

6. De qualquer modo, a atipicidade que acabamos de mencionar é subjetiva, porque emana do fato de o agente do ato, na compreensão comum, não poder praticar atos administrativos, impressão desmentida pela realidade (v.g. a nomeação de funcionário para serviços de tribunal) através de atos administrativos típicos. 
7. Outra atipicidade, entretanto, existe, a qual emerge da doutrina. É que veremos, a seguir.

Realmente, os mestres de processo civil (e, entre os nacionais, podem ver-se: JoÃo Mendes Júnior, Gabriel DE Rezende Filfo, Moacyr Amaral Santos e Paula Baptista) dão à palavra jurisdição ora o sentido de dizer do direito para pôr têrmo a demandas, ora o sentido de dizer do direito. O que, porém, já é reconhecido por êles (e Paula BAPTISTA chega a falar em "jurisdição administrativa", expressão que é, a um só tempo, reconhecimento de atividade administrativa do Juiz e contradição formal ao menos) é que, no dizer o direito aplicado ao fato, o juiz nem sempre está diante de autor e réu. Daí resulta que a atividade administrativa atípica realizada no cenário judicial do amigável sofre a resistência de ser reconhecida como o que é. Tal resistência, sob os nomes de "graciosa" ou "voluntária" ou de "partes in volentes", é clássica. Por isto, a atipicidade, ora caracterizada e à qual damos o nome de objetiva, ceflui de se pretender que as partes, na "jurisdição graciosa", vão a juízo porque a lei lhes impõe, mas, dependem de jurisdição, ainda que não sejam respectivamente autor e réu. É de se esclarecer, no entanto, que êste entendimento não pertence aos escritores processualistas (como os acima lembrados e tantos outros). Êle emana, todavia, de dois preconceitos:

a) o da visão unilateral de profissionais que vêm em todos os atos e têrmos de processo não apenas o judicial (o que estaria exato), mas, ainda o jurisdicional;

b) os "idola tribus" que levam juízes a dar a suas prolações em processos administrativos realizados em juízo o caráter sagrado de "res judicata pro veritate habetur".

7. Desnecessário é prosseguir no estudo da atipicidade, de que nos ocupamos neste artiguete. Os autores estão a reconhecê-la, já como processualistas, já como administrativistas. Se a regulação tradicional da chamada "jurisdição graciosa" é dos códigos de processo civil, deixá-la ficar ai, 
onde está bem, como sempre esteve. Não seja isto, entretanto, causa para que lhe neguem o que é de sua natureza. $\mathrm{E}$ o que é de sua natureza, ou antes: o que é de sua essência é ser atividade administrativa, da espécie: atos da administração publica do direito privado ${ }^{1}$. $\mathrm{E}$ isso se dá em virtude. de a lei exigir, para muitos atos de interêsse dos particulares a superestruturação plasmada em atos administrativos ${ }^{2}$.

III.

\section{A atipicidade na chamada “jurisdição graciosa” é o seu problema doutrinal cruciante.}

8. A justiça, formalmente considerada, atuará sempre através da jurisdição? A esta pergunta responde negativamente uma respeitável lição ${ }^{3}$. Mas, justiça material sabemos que pode ser feita até de homem para homem, nos limites da ordem jurídica ${ }^{4}$, e que, portanto, pode ser feita pelo juiz, excluída da jurisdição como fator de solução ${ }^{5}$. Êste argumento para aquêles que, como nós, entendemos que a tutela do direito, exclusão da fluida da jurisdição, é obra da administração pública no sentido material recon-duz plenamente nossa opinião ao ponto de partida do presente trabalho ${ }^{6}$. Também nós entendemos que tutelar o

1. A expressão é de Alberto HäNEL, como vem em citação de Zanobini (L'Amministrazione Pubblica del Diritto Privato), na Rivista di Diritto Público, vol. X (1912) p. 16 e nos Scritti Vari di Diritto Pubblico (1955), p. 19, nota 1 .

2. Esta circunstância exclui, desde logo a procedência do adjetivo "voluntária", que se costuma aditar à palavra "jurisdição", sempre que esta nada mais é do que "administração" Veja-se a extensa biblio-grafia que ZaNoBINI (ob, cit., p. 29 dos Scritti citados) oferece.

3. A de Zanoern! (ob. cit, nos Scritti, cits., p. 35).

4. Seria uma defesa preventiva do direito sob a forma privada.

5. Veja-se Zanobini (ob. cit., nos Scritti cits., p. 35) e GuÜcK (Commentario alle Pandette, II, parág. 193).

6. ZANOBINI (ob. cit., nos Scritti, p. 39, n. ${ }^{\circ} 7$ do texto) concede que seja administrativa - na chamada "jurisdição voluntária" apenas 
direito não é ùnicamente distribuir justiça, no sentido material, por isso que há tal tutela também em declarar direitos através de leis e manter a ordem externa e interna. Mas, o que não aceitamos é que a justiça material (possivel de ser realizada: pelos homens, nos limites da ordem jurídica; pelo Estado, através de órgãos judiciários e administrativos), não vinda da jurisdição e não endereçada nem a autor, nem a rél deixe de ser administração quando realizada através de atos vinculados. Por que? Precisamente porque, no campo do Direito Administrativo (onde, como é lógico também se faz justiça, nos limites da ordem jurídica) a vinculação não foi jamais obstáculo à identificação de um ato adininistrativo.

a parte em que o juiz tiver a seu favor o discricionário, porque argumenta êle - onde o administrado puder vir a ter direito no procedimento judicial subordinado à chamada "jurisdição voluntária" pressupõe-se que a lei (sem cuidar de contraste de interêsses ainda) submete ao juiz o caso em favor de temor de lesões de interêsses possíveis. 